\title{
Failure of Reach-Scale Restoration to Improve Biotic Integrity in a Mid-Atlantic Stream
}

\author{
William J. Meisenbach ${ }^{1}$, Helle Tychsen ${ }^{2}$, Christina Siu $^{2} \&$ Katherine H. Baker ${ }^{1}$ \\ ${ }^{1}$ Life Sciences Program, Penn State Harrisburg, 777 W. Harrisburg Pike, Middletown, Pennsylvania, USA \\ ${ }^{2}$ Environmental Engineering Program, Penn State Harrisburg 777 W. Harrisburg Pike, Middletown, Pennsylvania, \\ USA \\ Correspondence: Katherine H. Baker, Life Sciences Program, Penn State Harrisburg, 777 W. Harrisburg Pike, \\ Middletown 17057, Pennsylvania, USA. Tel: 1-717-948-6308. E-mail: khb4@psu.edu
}

Received: March 20, 2012 Accepted: April 10, 2012 Online Published: June 18, 2012

doi:10.5539/ep.v1n2p124 URL: http://dx.doi.org/10.5539/ep.v1n2p124

This research was supported by a Growing Greener Grant (\#4100041413) from the Pennsylvania Department of Environmental Protection

\begin{abstract}
Reach-scale restoration to re-establish habitat integrity is practiced throughout the US. These techniques, while yielding aesthetic enhancement, may not result in ecological improvement. Using a before-after, control-impacted (BACI) sampling design, we evaluated the benthic macroinvertebrate community in two branches of the Codorus Creek, Southeastern PA throughout the course of restoration projects. Reach-scale restoration activities at several sites along both branches have been conducted since 2002. There was no significant change in the benthic macroinvertebrate community associated with reach-scale restoration. Even after the restoration projects were completed, downstream-impacted sites on both branches reflected severe stress with reduced numbers of organisms, low diversity, and impoverished pollution sensitive species. Thus, our results indicate that there were no significant short-term benefits resulting from reach-scale restoration. We recommend that the actions of individuals and organizations concerned with streams focus on watershed-scale conservation and restoration activities.
\end{abstract}

Keywords: stream restoration, biotic integrity, macroinvertebrates, biomonitoring

\section{Introduction}

Flowing-water ecosystems (streams and rivers) throughout the United States have been severely degraded by the combined impacts of agriculture, industrial activities, and urbanization. The legacy of these impacts is reflected in urban and peri-urban streams with hydraulic instability, low water quality, and stressed depauperate biological communities (Morgan, Kline \& Cushman, 2007; Jones et al., 2001). Within recent decades, the field of stream restoration has emerged. This field uses a variety of engineering and conservation technologies to modify degraded streams with the ultimate goal of restoring them to a condition approaching that found before urbanization and its associated stressors (Cairns, 1991; Pedersen, Frierg, Skriver, Baatrup-Pedersen, \& Larsen, 2009). Numerous restoration projects have been conducted or currently are underway on streams and rivers. These projects have been heavily supported by local, state, and national regulatory agencies as well as a broad grass-roots movement and a rapidly growing market in consulting services to design and implement restoration projects (Lave, Doyle, \& Robertson, 2010). Bernhardt et al. (2007) estimated that expenditures for stream restoration in the US exceed 1 billion dollars annually.

In the majority of cases, restoration efforts focus on hydrological and habitat modifications on the scale of a reach or similar small segment of the stream that is degraded (Walsh et al., 2005; Roni et al., 2002; Kristensen, Baattrup-Pedersen, \& Thodsen, 2011). Planting and enhancing riparian vegetated buffers, stream channel modification to increase sinuosity, and building or stabilizing riffle-pool habitats through the modification and construction of in-stream systems, bank stabilization and riparian buffers are among the commonly used techniques in the majority of restoration projects (Selvakumar, O'Connor, \& Struch, 2010; Nilsson, Jansson, Malmqvist, \& Naiman, 2007; Schwartz \& Herricks, 2007; Sudduth \& Meyer, 2006). 
Restoration activities lead to cosmetic improvement to impacted streams; however, there is insufficient post-restoration monitoring for many projects to determine if there has been an improvement in biological conditions (Palmer et al., 2005; Kondolf \& Michel, 1995; Whiteway, Brown, Zimmerman, Venter, \& Grant, 2010; Buchanan,Walte, Nagle, \& Schneider, 2010). Despite the widespread implementation of restoration projects, only a minority include any post-project assessment (Bash \& Ryan, 2002; Tompkins \& Kondolf, 2007). Bernhardt et al. (2005) reported that fewer than $10 \%$ of restoration projects involved any post-project monitoring and outcomes assessment. While follow-up assessment of restoration projects may have increased in recent years, the majority of restoration projects still have no data to evaluate the success or failure of restoration. Even when post-restoration assessment has been conducted, much of the effort has focused on subjective evaluations (Moerke \& Lamberti, 2004), evaluations of hydrologic or geomorphic parameters (Buchanan, Walte, Nagle, \& Schneider, 2010), or general water chemistry conditions such as $\mathrm{pH}$ and turbidity rather than direct assessment of biological parameters (Klein, Clayton, Alldredge, \& Goodwin, 2007; Struck, Selvakuman, Hyer \& O'Connor, 2006). In the few cases where biological assessments have been conducted, the variability inherent in biological systems and the lack of well-defined assay techniques and biological endpoints has made it difficult to draw conclusions (Palmer et al., 2005; Purcell, Friedrich, \& Resh, 2002). Finally, the optimal time-frame over which biological assessment and monitoring should be conducted has not been established (Roni et al., 2002). Thus, the efficacy of steam restoration remains an open question (Hilderbrand, Watts, \& Randle, 2005).

We have examined the changes in the macroinvertebrates in a stream in South-Central Pennsylvania (Codorus Creek) during and over several years after the completion of stream reach restoration activities to evaluate the impact of these activities on the biology of the stream. Specifically, we have focused on examining the usefulness of short-term monitoring (1- 3 years post restoration) in demonstrating restoration outcomes.

\section{Materials and Methods}

\subsection{Study Site}

The Codorus Creek originates in West Manheim Township, Maryland and flows in a northeast direction through South-central Pennsylvania before it empties into the Susquehanna River near Saginaw, Pennsylvania. Cropland and woodland are the predominant land uses within the drainage basin; however, the impact of urban areas (e. g., the city of York, PA) is significant on the overall biotic integrity of the creek.

This study focused on the East and South Branches of the creek in the vicinity of York (2002-2009). This time period spans several restoration activities within both branches. Stream restoration began in February 2002 at one of the project sites located on the East Branch. The last site to undergo restoration was the impacted site on the South Branch, ending in January 2009. Samples were obtained at two sites along each branch of the Codorus Creek. Control samples (Sites East Branch Control and South Branch Control, respectively) were collected on the designated branch of the creek at a location upstream of any of the restoration activity. Thus, samples obtained from these sites reflected the baseline conditions of each branch. Impacted samples were collected from sites downstream of the restoration activities. These were sites within reaches of the stream that had been previously identified as degraded as a result of anthropogenic inputs (Hoch 2007). Restoration was performed at several areas between the control and impacted sites on both branches of the creek during the time period of this study (Table 1). Restoration activities were limited to reach-scale habitat improvement and included bank stabilization, installation of cross vanes, and creation/redefinition of riffle/pool habitat.

Table 1. Sampling and Restoration Sites on the Codorus Creek

\begin{tabular}{ccc}
\hline Name & $\begin{array}{c}\text { Map Location } \\
\text { (approximate latitude, longitude) }\end{array}$ & Condition \\
\hline SC & $39.7774,-76.7225$ & Reference \\
SI & $39.8129,-76.7532$ & Impacted \\
EC2 & $39.8201,-76.6481$ & Reference \\
EI & $39.8471,-76.6540$ & Impacted \\
\hline
\end{tabular}

Table 1, Sampling and Restoration Sites on the Codorus Creek falling within thearea of this study. Samples were taken at the control and impacted sites only. Project sites indicate areas between the control and impacted sites where restoration activities were conducted during this. 


\subsection{Macroinvertebrate Sampling}

Benthic macroinvertebrate communities were assessed using a Before-After-Control-Impacted (BACI) sampling design (Clements et al., 2009). This approach allowed us to monitor short-term (seasonal) variation within the stream while simultaneously tracking longer-term (multi-year) changes likely to be associated with restoration. Thus, concurrent changes at both the control and impacted sites were interpreted as indications of seasonal trends, with the life-cycle of the benthic macroinvertebrates, biotic interactions, or weather as likely causes, while divergent responses were considered to indicate alterations of the stream biota resulting from restoration activities.

Sampling was performed in the fall and spring at the designated locations. There was much wet weather for Fall 2008. Samples in 2008, therefore, could not be collected until the end of the fall season while in other years they were collected early in the fall. Spring collection for 2009 was postponed because March and April were very wet and the sampling criteria (samples were not collected immediately after a rainfall scour event greater than one centimeter; (Hoch, 2007) could not be easily met. Eventually, the March and April collections were cancelled. Macroinvertebrates were collected in July 2009, after a sufficient dry period.

Macroinvertebrates were collected using a dip net following the proportional sampling approach described in Barbour, Gerritsen, Snyer and Stribling (1999) and Chalfant (2007). A total of 10 jab samples were collected at each site with individual jabs allocated proportionally between reach habitats (riffle vs. pool). Net contents were transferred in bulk to buckets placed on ice and returned to the laboratory $(<6 \mathrm{hrs})$ where they were preserved for sorting and identification.

Samples were split in half and larvae were picked visually from one of the subsamples. The samples also were checked under a dissecting microscope to ensure that all larvae had been removed. Each sample was examined independently by two individuals as a check on completeness. Macroinvertebrates were identified (family-level) using standard keys (Peckarsky, Fraissinet, Penton, \& Conklin, 1990; Merritt, Cummins, \& Berg, 2008).

Community structure and diversity were analyzed using the Index of Biotic Integrity (IBI) as described in the published guidelines of U.S. Federal and State regulatory agencies (Barbour, Gerritsen, Snyder, \& Stribling, 1999; Chalfant, 2007). This index is a weighed multimetric index incorporating measures of community diversity, abundance, richness, and pollution tolerance. Because there was only a single sample collected for each site at each sampling time, the IBI was graphed as a function of time and visually compared for any trends or patterns. In addition, the sampling times were divided into three categories - pre-restoration, restoration, and post-restoration for statistical comparison of the impact of restoration. Control and impacted sites were compared over each of these categories using 2-way ANOVA (GraphPad Prism).

\section{Results}

Figures 1 and 2, respectively, summarize the Index of Biotic Integrity for the East and South Branches of the Codous Creek. There were no apparent temporal trends in the IBI; although, in general, the IBI for samples collected in the fall was lower than spring samples. Furthermore, visual examination of the graphs indicated that the IBI at the impacted site generally paralleled, but consistently remained lower than, the IBI at the control site.

Given the unusual weather circumstances and the delay in collection associated with the post-restoration (Fall 2008 and Spring 2009) samples, it is likely that the slight increase in IBI seen in the spring 2009 East Branch sample (Figure 1A) is a reflection of seasonal differences in macroinvertebrate communities rather than post-restoration improvement of the macroinvertebrate community. Tikkanen, Laasonen, Muotka, Huhta and Kuusela (1994) stressed the importance of seasonality in evaluating macroinvertebrate communities, noting that a difference of less than three weeks could have a significant effect on the composition and diversity of the community. In our study, post-restoration sampling was delayed by almost 2 months due to weather conditions. Thus, it would be unwarranted to interpret the anomalous IBI value for the Spring 2009 sample as an early indication of a trend. Additional samples would be required to demonstrate if such improvement indeed were occurring. Comparisons of the pre-, during-, and post-restoration samples for both the East Branch (Figure 1B) and the South Branch (Figure $2 \mathrm{~B})$ indicated there were no significant $(\mathrm{p}=0.05)$ differences between these times. Thus, in the time-frame of this study, neither a significant detrimental impact of restoration activities during the period of active restoration nor post-restoration improvement of the macroinvertebrate community could be documented. 


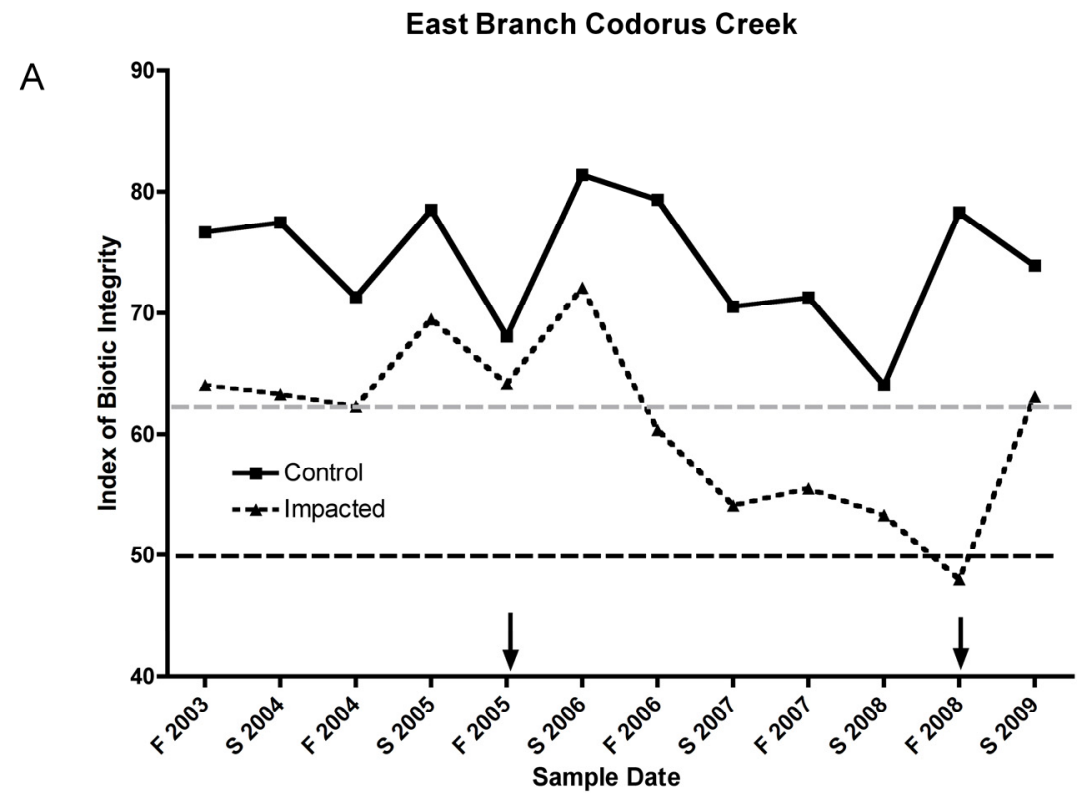

East Branch Codorus Creek

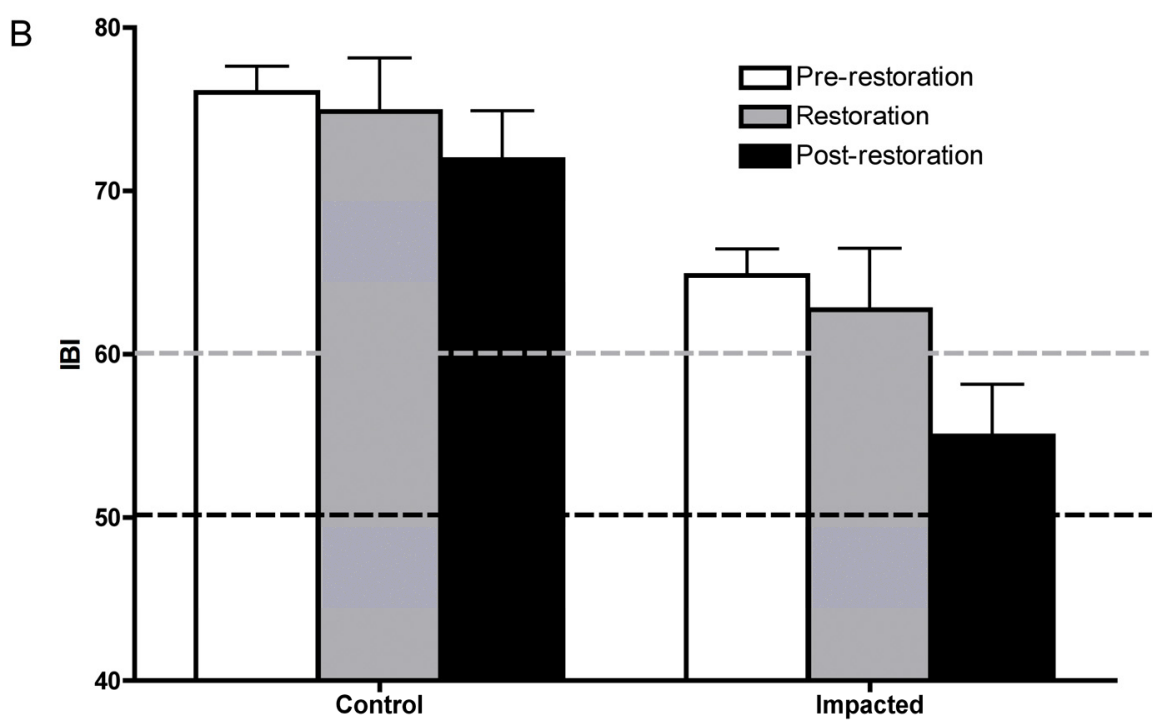

Figure 1. Macroinvertebrate Diversity: East Branch Codorus Creek

Figure 1, East Branch of the Codorus Creek (A) Temporal variation in Index of Biotic Integrity for Benthic Macroinvertebrates. Macroinvertebrates were collected and analyzed as described in Section 2.2. Vertical arrows on the graph indicate the dates when restoration activities were begun and completed. Horizontal dashed lines indicate PA DEP attainment levels for biotic integrity for samples collected between October and May (grey line) and at other times of the year (black line). (B) Comparison of grouped (pre-restoration, during restoration, and post restoration) IBI values for control and impacted sites. Bars indicate $+/-$ one standard deviation. Horizontal dashed lines indicate healthy IBI values as described for part (A). 
A

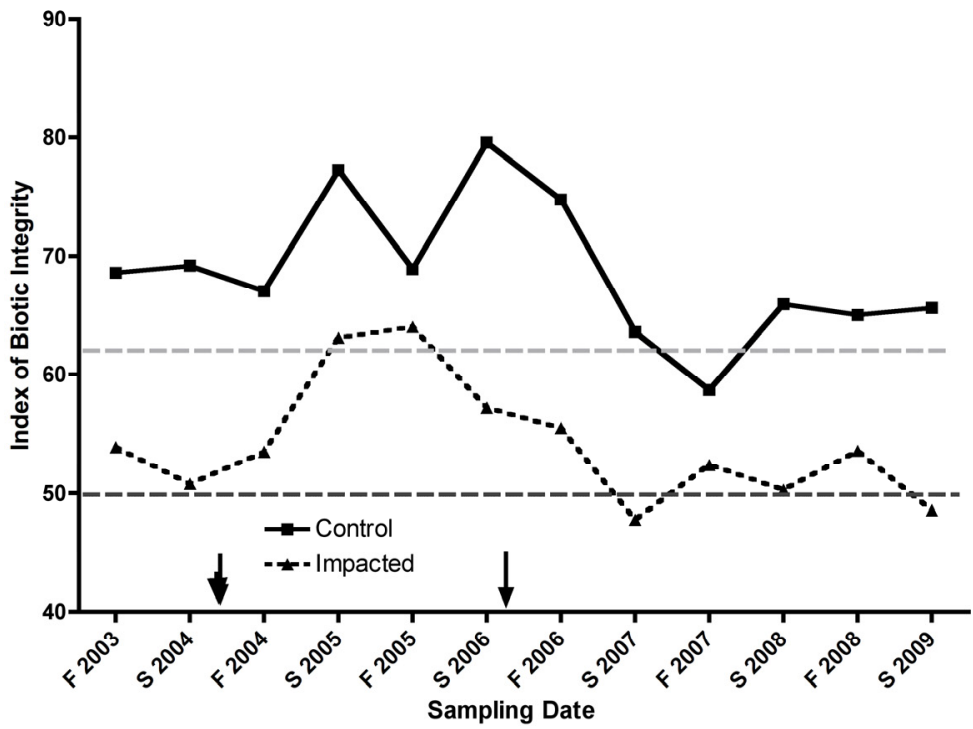

South Branch Codorus Creek

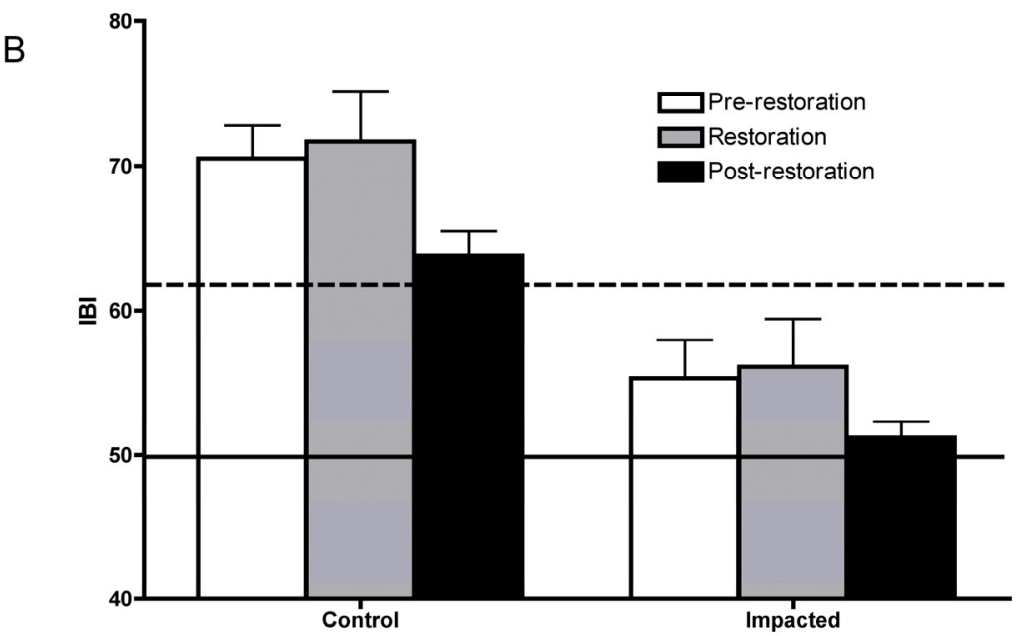

Figure 2. Macroinvertebrate Diversity: South Branch Codorus Creek

Figure 2, South Branch of the Codorus Creek (A) Temporal variation in Index of Biotic Integrity for Benthic Macroinvertebrates. Macroinvertebrates were collected and analyzed as described in Section 2.2. Vertical arrows on the graph indicate the dates when restoration activities were begun and completed. Horizontal dashed lines indicate PA DEP attainment levels for biotic integrity for samples collected between October and May (grey line) and at other times of the year (black line). (B) Comparison of grouped (pre-restoration, during restoration, and post restoration) IBI values for control and impacted sites. Bars indicate $+/-$ one standard deviation. Horizontal dashed lines indicate healthy IBI values as described for part (A).

\section{Discussion}

The majority of stream restoration projects within the US and Western Europe are based on the assumption that modification of the stream habitat to pre-development conditions is the driving force behind the re-establishment of a robust biotic community. In other words, with the right diverse habitat, the natural biological system will become (re)established. Pederson, Frierg, Skriver, Baatrup-Pedersen and Larsen (2009) found significant improvement in macroinvertebrate diversity immediately after large-scale $(>19 \mathrm{~km})$ restoration of the Skjern River which they attributed to colonization of downstream restored areas by taxa from upstream sources. Tikkanen, Laasonen, Muotka, Huhta and Kuusela (1994), on the other hand, found that the implementation of restoration projects had a minimal impact on stream macroinvertebrates causing a slight decrease in the 
abundances of benthic insects lasting less than 2 weeks followed by rapid improvement in the biological community. Our results failed to document any post-restoration detrimental impact on the macroinvertebrate community, although this may reflect the time elapsed between the restoration activities and collection of the macroinvertebrate samples. Furthermore, our results did not demonstrate any improvement in the macroinvertebrate community after restoration activities were completed.

In a meta analysis of stream projects, Palmer et al. (2005) found that the vast majority of stream habitat restoration projects had either no monitoring, precluding an evaluation of successful reestablishment of macroinvertebrate communities, or failed to demonstrate statistically significant differences between control reaches and post-restoration reaches. Stream ecosystems are known to be highly variable from year to year, thus, a large number of samples is needed in order to have sufficient statistical power to detect subtle changes occurring over a short time-frame. And yet, the majority of stream restoration monitoring programs depend on a minimal number of samples with little or no measures of sample variance (Palmer, Menninger, \& Bernhardt, 2009). The failure of our study to detect changes in the macroinvertebrate community post-restoration may reflect the limited number of samples obtained and underscores the importance of considerations of statistical power in the design of restoration monitoring projects. Of course, these statistical considerations must be balanced against the high costs, in terms of resources, time, and money, required for extensive monitoring.

Degraded streams frequently reflect the influence of multiple stressors integrated over long time periods. In addition to direct alterations in stream hydrology and geomorphology, streams function as a sink for materials, both natural and anthropogenic, generated in the surrounding land. Urban and agricultural runoff (Wang, Lyons, Kanehl, \& Bannerman, 2001; Walsh, Roy, Feminella, Cottingham, Groffman, \& Morgan, 2005; Meyer, Paul \& Taulbee, 2005; Chadwick et al., 2006), point source inputs from municipal and industrial waste treatment facilities (Ogunfowokan, Okon, Adenuga, \& Asubiojo, 2005; Santhi, Arnold, Williams, Hauck, \& Dugas, 2001), deforestation (Sweeney et al., 2004), and a myriad of other changes within the watershed ultimately influence stream organisms. Stream restoration via habitat restoration addresses only a subset of the possible stressors that influence stream biota and thus may not be associated with restoration of biotic parameters (Sundermann et al., 2011). Furthermore, as this study reflects restoration often is limited to the scale of the stream reach and does not include upstream or watershed-wide stressors. The impact of such reach-scale restoration activities is unlikely to be associated with large-scale alterations in the health of the stream biota.

\section{Conclusion}

Stream restoration is a multi-billion dollar industry within the U.S. and yet, the efficacy and long-term benefits of stream restoration via habitat enhancement and modification have not been demonstrated. Our data supports the contention that reach-level stream restoration via habitat restoration may not be a cost effective approach to the re-establishment of a healthy stream biota. Restoration of biotic integrity is a slow process and a period of several years may not be sufficient for healthy macroinvertebrate populations to become re-established. Furthermore, our study underscores the importance of upstream and watershed scale factors, such as point and non-point nutrient inputs on the outcome of restoration. Reach-level restoration should be viewed as a step in a continuing process of restoration focusing on the entire watershed. Instead of spending vast amounts of money on scattered individual small-scale projects, the public would be better served by allocating resources to comprehensive planning and implementation of practices to preserve and restore watersheds as a whole rather than fragmented areas.

\section{Acknowledgements}

The authors thank Danielle Harrow, Natasha Nicholson, and Izmir Akhmedov for their assistance with sample collection.

\section{References}

Barbour, M. T., Gerritsen, J., Snyder, B. D., \& Stribling, J. B. (1999). Rapid Bioassessment Protocols for Use in Streams and Wadeable Rivers: Periphyton, Benthic Macroinvertebrates and Fish (2nd Ed.). EPA 841-B-99-002. U.S. Environmental Protection Agency, Office of Water, Washington, D.C.

Bash, J. S., \& Ryan, C. M. (2002). Stream restoration and enhancement projects: Is anyone monitoring? Environmental Management, 29(6), 877-885. http://dx.doi.org/10.1007/s00267-001-0066-3

Bernhardt, E. S., Palmer, M. A., Allan, J. D., Alexander, G., Banas, K., Brooks, S., ... Sudduth, E. (2005). $\begin{array}{lllll}\text { Synthesizing U.S. River Restoration Efforts. Science, 308(5722), 636-737. } & \text {. }\end{array}$ http://dx.doi.org/10.1126/SCIENCE.1109769

Bernhardt, E. S., Sudduth, E. B., Palmer, M. A., Allan, J. D., Meyer, J. L., Alexander, G., ... Pagano, L. (2007). Restoring rivers one reach at a time: results form a survey of U.S. river restoration practitioners. Restoration 
Ecology, 15(3), 482-498. http://dx.doi.org/10.1111/J.1526-100X.2007.00244.x

Buchanan, B. P., Walte, M. T., Nagle, G. N., \& Schneider, R. L. (2010). Monitoring and assessment of a river restoration project in central New York. River Restoration and Applications, 27. http://dx.doi.org/10.1002/rra1453.

Cairns, J. (1991). The status of the theoretical and applied science of restoration ecology. Environmental Professional, 13(3), 186-194.

Chadwick, M. A., Dobberfuhl, D. R., Benke, A. H., Huryn, A. D., Suberkropp, K., \& Thiele, J. E. (2006). Urbanization affects stream ecosystem function by altering hydrology, chemistry, and biotic richness. Ecological Applications, 16(5), 1796-1807.

Chalfant, B., PaDEP (Pennsylvania Department of Environmental Protection) (2007). A Benthic Index of Biotic Integrity for Wadeable Freestone Riffle-Run Streams in Pennsylvania. Retreived from www.depweb.state.pa.us/portal/server.pt/document/.../ibi_rifflerun_pdf.

Clements, W. H., Carlisle, D. M., Courtney, L. A., \& Harrahy, E. A. (2009). Integrating observational and experimental approaches to demonstrate causation in stream biomonitoring studies. Environ.Toxicol.Chem., 21(6), 1138-1146. http://dx.doi.org/10.1002/3tc.5620210605.

Hilderbrand, R. H., Watts, A. C., \& Randle, A. M. (2005). The myths of restoration ecology. Ecology and Society, 10(1), 19. Retrieved from http://www.ecologyandsociety.org/vol10/iss1/art19/

Hoch, M. P. (2007). CCREP: Codorus Creek Restoration Efficacy Program: Pre-restoration Assessment Final Data Report (\#SC30462). Department of Environmental Protection, Harrisburg, Pennsylvania.

Jones, K. B., Neale, A. C., Nash, M. S., Van Remortel, R. D., Wickhan, J. D., Ritters, K. H., \& O’Neill, R. V. (2001). Predicting nutrient and sediment loadings to streams from landscape metrics. A multiple watershed study from the United States Mid-Atlantic Region. Landscape Ecology, 16(4), 301-312.

Klein, L. R., Clayton, S. R., Alldredge, J. R., \& Goodwin, P. (2007). Long-term monitoring and evaluation of the lower Red River Meadow restoration project, Idaho, U. S. A. Restoration Ecology, 15(2), 223-239.

Kondolf, G. M., \& Michel, E. R. (1995). Evaluating stream restoration projects. Environmental Management, 19(1), 1-15.

Kristensen, E. A., Baattrup-Pedersen, A., \& Thodsen, H. (2011). An evaluation of restoration practices in lowland streams: Has the physical has integrity been re-created? Ecological Engineering, 37(11), 1654-1660. http://dx.doi.org/10.1016/j.ecoleng.2011.06.043

Lave, R., Doyle, M., \& Robertson, M. (2010). Privitizing stream restoration in the U.S. Social Studies of Science, 40(5), 677-703. http://dx.doi.org/10.1177/0306312710379671

Merritt, R. W., Cummins, K. W., \& Berg, M. B. (2008). An Introduction to the Aquatic Insects of North America (4th ed.). Dubuque, IA: Kendall. Hunt Publishing Co.

Meyer, J. L., Paul M. J., \& Taulbee, W. K. (2005). Stream ecosystem function in urbanizing landscapes.Journal of the North American Benthological Society, 24(3), 602-612.

Moerke, A. H., \& Lamberti, G. A. (2004). Restoring stream ecosystems: lessons from a Midwestern state. Restoration Ecology, 12(3), 327-334. http://dx.doi.org/10.1111/J.1061-2971-2004.0340x

Morgan II, R. P., Kline, K. M., \& Cushman, S. F. (2007). Relationships among nutrients, chloride and biological indices in urban Maryland streams. Urban Ecosystems, 10(2), 153-166. http://dx.doi.org/10.1007/s11252-006-0016-1

Nilsson, C., Jansson, R., Malmqvist, B., \& Naiman, R. J. (2007). Restoring riverine landscapes: the challenge of identifying priorities, reference states, and techniques. Ecology and Society, 12(1), 16. Retrieved from http://www.ecologyandsociety.org/vol12/iss1/art16

Ogunfowokan, A. O., Okon, E. K., Adenuga, A. A., \& Asubiojo, O. I. (2005). An assessment of the impact of point source pollution from a university sewage treatment oxidation pond on a receiving stream - A preliminary study. Journal of Applied Sciences, 5(1), 36-45.

Palmer, M. A., Bernhardt, E. S., Allan, J. D., Lake, P. S., Alexander, G., Brooks, S., ... Sudduth, E. (2005). Standards for ecologically successful river restoration. Journal of Applied Ecology, 42(2), 208-217. http://dx.doi.org/10.1111/J.1365-2664.2005.01004.x

Palmer, M. A., Menninger, H. L., \& Bernhardt, E. S. (2009). River restoration, habitat heterogeneity and 
biodiversity: a failure of theory and practice? Freshwater Biology, 55, 1-18.

Peckarsky, B. L., Fraissinet, P., Penton, M. A., \& Conklin, D. J. Jr. (1990). Freshwater Macroinvertebrates of Northeastrn North America. Ithica, New York: Cornell University Press, 442.

Pedersen, M. L., Frierg, N., Skriver, J., Baatrup-Pedersen, A., \& Larsen, S. E. (2009). Restoration of Skjern River and its valley - short-term effects on river habitats, macrophytes, and macroinvertebrates. Ecological Engineering, 30(2), 145-156. http://dx.doi.org/10.1016/J.ECOLENG.2006.08.009

Purcell, A. H., Friedrich, C., \& Resh, V. H. (2002). An assessment of a small urban stream restoration project in $\begin{array}{lllll}\text { Northern } & \text { California. } & \text { Restoration }\end{array}$ http://dx.doi.org/10.1046/J.1526-100x.2002.01049.x

Roni, P., Beechee, T. J., Bilby, R. E., Leonetti, F. E., Pollock, M. M., \& Press, G. R. (2002). A review of stream restoration techniques and a hierarchial strategy for prioritizing restoration in the Pacific Northwest watersheds. North American Journal of Fisheries Management, 22(1), 1-20. http://dx.doi.org/10.1577/1548-8675(2002)022<0001:AROSRT>2.0.CO;2

Santhi, C., Arnold, J. G., Williams, J. R., Hauck, L. M., \& Dugas, W. A. (2001). Application of a watershed model to evaluate management effects on point and nonpoint source pollution. Transactions of the American Society of Agricultural and Biological Engineers, 44(6), 1559-1570.

Schwartz, J. S., \& Herricks, E. E. (2007). Evaluation of pool-riffle naturalization structures on habitat complexity and the fish community in an urban Illinois stream. River Research and Applications, 23(9), 451-466. http://dx.doi.org/10.1002/rra.986

Selvakumar, A., O'Connor, T.P., \& Struch, S. D. (2010). Role of stream restoration on improving benthic macroinvertebrates and in-stream water quality in an urban watershed: a case study. Journal of Environmental Engineering, 136(1), 127-139. http://dx.doi.org/10.1061/(ASCE)EE.1943-7870.0000116

Struck, S. D.,Selvakumar, A., Hyer, K., \& O'Connor, T. (2006). Evaluating the Accotink Creek Restoration Project for improving water quality, in-stream habitat, and bank stability. Proceedings of the World Environmental and Water Resources Congress 2006: Examining the Confluence of Environmental and Water Concerns. American Society of Civil Engineers. Omaha, Nebraska. May 22-25, 2006.

Sudduth, E. B., \& Meyer, J. L. (2006). Effects of bioengineered streambank stabilization on bank habitat and macroinvertebrates in urban streams. Environmental Management, 382, 218-226. http://dx.doi.org/10.1007/s00267-004-0381-6

Sundermann, A., Antons, C., Cron, N., Lorenz, A. W., Hering, D., \& Haase, P. (2011). Hydromorphological restoration of running waters: effects on benthic invertebrate assemblages. Freshwater Biology, 56, 1689-1702.

Sweeney, B. W., Bott, T. L., Jackson, J. K., Kaplan, L. A.,Newbold, J. D.,Standley, L. J.,Hession, W. C., \& Horowitz, R. J. (2004). Riparian deforestation, stream narrowing, and loss of stream ecosystem services. Proceedings National Academy of Sciences, 101(39), 14132-14137. http://dx.doi.org/10.1073/pnas.0405895101

Tikkanen, P., Laasonen, P., Muotka, T., Huhta, A., \& Kuusela, K. (1994).Short-term recovery of benthos following disturbance from stream habitat rehabilitation. Hydrobiologia, 273(2), 121-130. http://dx.doi.org/10.1007/BF00006854

Tompkins, M. R., \& Kondolf, G. M. (2007). Systematic post project appraisals to maximize lessons learned from river restoration projects: case study of compound channel projects in Northern California. Restoration Ecology, 15(3), 524-537. http://dx.doi.org/10.1111/j.1526-100x.2007.00248.x

Walsh, C. J., Roy, A. H., Feminella, J. W., Cottingham, P. D., Groffman, P. M., \& Morgan, R. P. (2005). The urban stream syndrome: current knowledge and the search for a cure. Journal of the North AmericanBenthological Society, 24(3), 706-723.

Wang, L., Lyons, J., Kanehl, P., \& Bannerman, R. (2001). Impacts of urbanization on stream habitat and fish across multiple spatial scales. Environmental Management, 28(2), 255-266. http://dx.doi.org./10.1007/s0026700-10222

Whiteway, S. L., Brown, P. M., Zimmerman, A., Venter, O., \& Gant, J. W. A. (2010). Do in-stream restoration structures enhance salmonid abundance? A meta-analysis. Canadian Journal of Fisheries and Aquatic Sciences, 67(5), 831-841. http://dx.doi.org./10.1139/F10-021 